\title{
DINHEIRO PARA A GUERRA: AS DÉCIMAS DA RESTAURAÇÃO
}

\author{
por \\ JOAQUIM ROMERO MAGALHÃES \\ Universidade de Coimbra
}

RESUMEN: Este artículo analiza el esfuerzo fiscal llevado a cabo por la comunidad política portuguesa durante la Guerra de la Restauración, con especial atención al impuesto denominado «décima militar». Este tributo tuvo la peculiaridad de ser general y proporcional, ya que, una vez aprobado por las cortes de 1641, debian satisfacerlo todos los estamentos del reino sin excepción y de acuerdo al porcentaje establecido. Los conflictos y resistencias que este nuevo orden fiscal ocasionó en la política interna del Portugal Restaurado no ban sido estudiados hasta boy de forma sistemática. Estas páginas pretenden ser la primera investigación moderna al respecto.

Palabras Clave: Portugal. Guerra de Restauración. Fiscalidad. Décima Militar. Resistencia.

ABSTRACT: This article addresses the fiscal strategies undertaken by the Portuguese political community during the War of the Restoration, which special attention to the tax known as the "military tentb». This tax was distinguished by being both general and proportional, since once it bad been approved by the Cortes of 1641 it bad to be paid by all estates in the kingdom, without exception, and in accordance with the established percentage. The conflicts and forms of resistance which these new fiscal demands set in motion in Portuguese politics have not been systematically studied before now; the following pages represent the first modern research on the topic.

KEY WORDS: Portugal. War of the Restoration. Taxation. Finance. Resistance.

«Seja Deos louvado que me chegou a ver coroar hum Rey Portugués tam desejado neste Reino», exultava o escrivão do povo de Lisboa Bartolomeu Pe- 
reira, em Dezembro de $1640^{1}$. Seria este o anseio de muitos, e a aclamação na capital ocorreu sem dificuldades. Tirar um rei e pôr outro fora fácil. Sem luta ${ }^{2}$. D. João IV foi em seguida aclamado por todo o País. Mas muitos também sabiam que o pior estava para vir. Agora «havia, senão maiores, outras dificuldades que vencer» ${ }^{3}$. Complicado e moroso se previa o esforço militar para sustentar no trono o «rei natural» 4 . Sabia-se que as coisas se iam tornar duras. $O$ Reino que resistira quanto pudera à fiscalidade dos Felipes tinha agora que pagar pela sua independência sentida como recobradas. Porque Felipe IV de Castela, que deixava de ser reconhecido como rei em Portugal, não iria sofrer sem acções armadas que esta sua herança patrimonial lhe escapasse ${ }^{6}$. Porque assim o impunha o seu sentir e a sua autoridade e reputação, duramente feridas com o golpe de Estado que pusera no trono o Duque de Bragança. Era inverosímil que isso pudesse ter acontecido $7 . .$.

Montar uma defesa capaz era a imediata e principal das preocupações do novo monarca e dos começavam a chegar-se-lhe. Poucos eram os cabos de guerra. Os recursos anteviam-se escassos. Estas seriam as principais dificuldades para fazer com que a nova dinastia defendesse, conservasse e governasse o reino. Fortificações, navios, tropas e dinheiro. Sobretudo dinheiro. Os governadores que aguardam a chegada do novo rei a Lisboa procuram logo saber do Conselho da Fazenda os meios disponíveis para «a defesa e segurança destes Reinos» ${ }^{8}$. A criação do Conselho de Guerra, logo do dia 11 de Dezembro, diz tudo: a defesa das fronteiras era imperativo de sobrevivência para a nova situação política9.

Iniciam-se logo os preparativos militares para suprir as faltas em «soldados, disciplina, cavalos, armas e dinheiro» ${ }^{10}$. Mudam-se os comandos militares que

1 Carvalho, J. M. Teixeira de: Notas de um escrivão do povo, Coimbra, Imprensa da Universidade, 1922, p. 13.

${ }^{2}$ Almeida, M. Lopes de: Relação de tudo o que passou na felice aclamaşão, Coimbra, Atlântida, 1939 , p. 18.

3 Ericeira, Conde da: História de Portugal Restaurado, Porto, Livraria Civilização, 1945, vol. I, p. 125.

${ }^{4}$ GodinHo, Vitorino Magalhães: «1580 e a Restauração», in Ensaios, II, Sobre história de Portugal, Lisboa, Sá da Costa, 1976, pp. 381-421.

5 Oliveira, António de: "Oposição política em Portugal nas vésperas da Restauração» in Movimentos Sociais e Poder em Portugal no século XVII, Coimbra, Instituto de História Económica e Social - Faculdade de Letras, 2002, pp. 689-717.

6 VAlladares, Rafael: La rebelión de Portugal, 1640-1680. Guerra, conflicto y poderes en la monarquía bispánica, Valladolid, Junta de Castilla y León, 1998, pp. 31-37 e 45-52.

7. ElliotT, John H.: El Conde-Duque de Olivares. El político en una época de decadencia, trad., $5^{\mathrm{a}}$ ed., Barcelona, Editorial Crítica, 1991, p. 580.

8 SILVA, José Justino de Andrade e: Colleç̧ão chronologica da legislação portugueza, 1640-1647, Lisboa, Imprensa de F. X. de Souza, 1856, p. 9.

9 GUIMARÃES, Vitorino: «As finanças na Guerra da Restauração (1640-1668)», sep. da Revista Militar, Lisboa, 1941, p. 16.

10 Ericeira, Conde da: História de Portugal Restaurado, vol. I, p. 143.

Hispania, LXIV/1, núm. 216 (2004) 157-182 
até aí tinham rotineiramente assegurado a defesa do Reino. Capitães-mores e governadores nomeados são mandados para os respectivos lugares, que geralmente iam ocupar por pouco tempo ${ }^{11}$. E que na corte recém-formada logo se começam a ouvir «vozes das sereias do Paço, verdugos dos Príncipes, sepultura dos reinos» ${ }^{12}$. No meios de intrigas e malquerenças palacianas se começam a montar as defesas.

De imediato também há quem veja a necessidade de contribuir para a fazenda régia. O Cabido da Sé de Coimbra dispõe-se mesmo a oferecer todas as rendas da mesa capitular, a prata das igrejas e o cobre dos sinos ${ }^{13}$. Medida antiga, que há muito não se efectivava. Que pressupunha que se esperasse possível uma campanha militar rápida. No entanto, a prudência mandava que se previsse que a guerra duraria, fosse ela ofensiva ou defensiva. Nada fazia esperar um desfecho rápido. Por isso, a necessidade de criar um novo tributo com finalidade militar, que fosse estável e de cobrança relativamente suave. O que apresentava grandes dificuldades: fora em boa parte para fugir à fiscalidade excessiva - e desordenada - de Felipe IV que a restauração se fizera.

Logo em 23 de Dezembro de 1640 o rei escreve aos municípios com representação em cortes determinando que elejam procuradores para uma reunião dos Três Estados. Desejando «comprir inteiramente com as obrigações que tenho de defender, conseruar e governar estes meus Reynos que Deos foi seruido de me restituir, e entendendo que para se acertarem cousas de tão grande importancia he conveniente e necessario comunical-las com os tres Estados da Nobreza, prelados e pouos delles» ${ }^{14}$. Pelas cidades e vilas que gozavam desse privilégio, executou-se o mandado.

Chegam os procuradores às cortes a Lisboa, onde se vão reunir no Paço da Ribeira, a 28 de Janeiro de 1641. Começam por jurar o novo monarca e o príncipe herdeiro D. Teodósio. Para logo de seguida tratarem do que dói: a indispensável tributação extraordinária para sustentar a guerra. Entendia o rei que «não são bons os tributos que com lagrimas se pagam, senão só os serviços que oferece o coração». Por isso o rei desde logo declara levantar «todos quantos tributos os Reis de Castella vos impozeram, no tempo que indevidamente occuparam estes Reinos» ${ }^{15}$. O que passou a letra de lei em 27 de Fevereiro de $1641^{16}$. Era uma

\footnotetext{
11 MAGAlHÃes, Joaquim Romero: «Algumas notas críticas sobre a História da Restauração Portuguesa (1640-1668)", in ANDRADE, Manuel Correia de, FERNANDES, Eliane Moury, e CAVALCANTI, Sandra Melo (org.), Tempo de Flamengos $\mathcal{E}$ outros tempos, Recife, Fundação Joaquim Nabuco Editora Massangana, 1999, p. 339.

12 Ericeira, Conde da: História de Portugal Restaurado, vol. I, p. 396.

13 Almeida, M. Lopes de: Notícias da aclamação e de outros sucessos, Coimbra, 1940, pp. CL.

${ }_{14} O$ Pôrto na Restauração. Subsídios para a sua História, tomo I, Porto, Publicações da Câmara Municipal do Porto, 1941, p. 18.

is Silva: Colleç̧ão, 1640-1647, p. 25.

16 Oliveira, Eduardo Freire de: Elementos para a Historia do Municipio de Lisboa, Lisboa, Typographia Universal, tomo IV, p. 423; SILVA: Colleç̧ão, 1640-1647, p. 74.
} 
forma simbólica de cortar com o passado. De regressar a 1581. Todavia, tornava-se premente que agora se buscassem «meios suaves e justos» para acudir às necessidades presentes. O Reino agradeceu o levantamento dos aborrecidos tributos «que tiranicamente estavam impostos pelos Reis de Castela, com que o povo estava duramente opprimido" ${ }^{17}$. E dispôs-se a contribuir com o que fosse indispensável, porque era «mais acção dar tudo por amor, que pouco por violência» ${ }^{18}$. Trazer 0 assunto às cortes significava que o rei procurava implicar as mais representativas personagens e os corpos sociais tradicionalmente dispensados nas gravosas medidas fiscais que tinham que ser tomadas. Sem demora. Aceites em cortes, era de supor que por todos fossem cumpridas. A fazenda era bem «o nervo da guerra, mas também o fundamento com que se sustenta o Reino, assim na mesma guerra, como na paz» ${ }^{19}$.

Começam então a ser discutidos, pelos representantes divididos nos três corpos orgânicos, os novos tributos que se calculam deverem render anualmente 2 milhões de cruzados. Em que todos deveriam pagar, mesmo que para isso se falasse de coisas diferentes: os fidalgos tratavam de avançar com um donativo; os eclesiásticos com uma finta. «Os povos tratão de consentir no real dagoa ou por huns tantos anos, ou emquanto durarem as guerras com Castella porquanto o Reino ficou muito esfolado» ${ }^{20}$. Era 0 que ia constando na cidade que se estava tratando nas cortes. Preventivamente, os procuradores desde logo apresentam ao monarca o seu desejo de que o donativo ou serviço que viesse a ser votado para a defesa do Reino «não possa em tempo algum ser exemplo, para Vossa Magestade, ou seus legitimos Successores, o requererem, ou pertenderem, por tributo ou imposição, nem para o allegarem por cousa obrigatoria, para lhes haver de ser concedido outro semelhante serviço» ${ }^{21}$. Assim acontecerá. As declarações de excepcionalidade não faltarão, ao longo de muitos anos, de todos os anos que houve de guerra. E em que o tributo extraordinário se lançou.

Afinal, votou-se um subsídio de 1800 mil cruzados, durante três anos se a guerra tanto durasse, para sustentar um exército de 20000 homens de infantaria e 4000 de cavalaria. Mas agora esse montante seria junto pela cobrança da décima parte do que valessem os rendimentos das fazendas dos vassalos ${ }^{22}$. De todos, «não se exceptuando género algum de pessoa que deixasse de contribuir a dez por cento de qualquer qualidade de fazenda de que fosse senhor ${ }^{23}$. Era um tributo geral que incidia sobre todos os vassalos e tendencialmente proporcional aos rendimentos de cada um. Duas novidades. Que não podiam ser bem aceites pelos privilegiados, assim equiparados à gente popular. E que ia contra

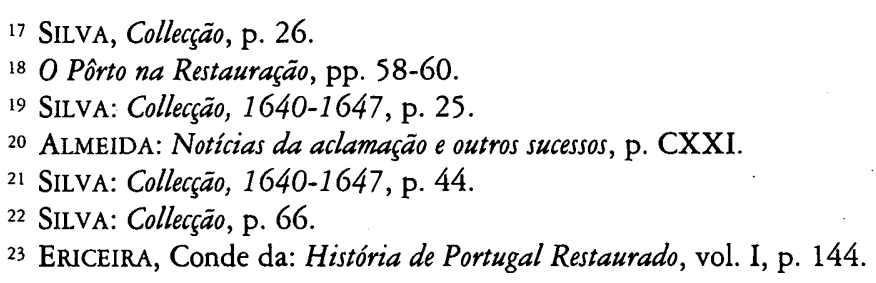


tudo o que até então acontecera em matéria fiscal. Nem o odiado Conde de Olivares alguma vez conseguira avançar com nada de semelhante ${ }^{24}$. E não por falta de vontade.

No entanto, o estado de necessidade do Reino leva a que os eclesiásticos contribuam "voluntariamente». A parte deles será dita um donativo, embora proporcional ao que valia cada bispado ${ }^{25}$. Declarando-se para mais que isso acontecia «sem offender a immunidade Ecclesiástica». Também os comendadores não ficariam isentos. As décimas das comendas, mesmo das vagas, teriam que ser pagas. Todos os vassalos, independentemente da sua qualidade e condição, concorreriam «no meo que se tem tomado $\mathrm{E}$ esta approuado pelo Ecclesiastico $\mathrm{E}$ secular de que todos paguem a Decima, de suas fazendas $E$ rendas, para os gastos das guerras " ${ }^{26}$. Alguns bispos apoiaram a disposição das cortes, como o Arcebispo de Lisboa $\mathrm{D}$. Rodrigo da Cunha que bem explica a todas as pessoas eclesiásticas da sua diocese que a décima «será taxada conforme ao valor e rendimento de seus benefícios e bens patrimoniaes» ${ }^{27}$. O rei não isentou ninguém do pagamento ${ }^{28}$. Era o meio mais suave e de mais utilidade para todos ${ }^{29}$.

Este «dinheiro pronto e efectivo» vai contudo mostrar-se difícil de "repartição e cobrança». Tendo consultado pessoas de "qualidade, experiência e zelo" o rei determina à câmara de Lisboa que a distribuição se fizesse de um modo fixo. Assim, em cada mês pagariam:

Fidalgòs que não fossem pobres

VINTÉNS

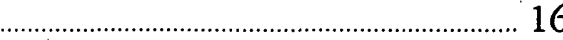

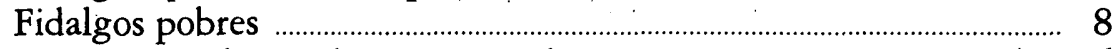

Desembargadores e homens togados ............................................................. 16

Desembargadores e homens togados pobres ................................................. 8

Homens do meio e cidadãos ...................................................................... 4

Homens do meio e cidadãos ricos .............................................................. 16

Homens de trato ou meneio grosso .................................................................. 16

Homens de trato ou meneio grosso de menos cabedal ............................. 8

Mercadores de lojas de sedas e panos ……………………………………....... 16

Mercadores de lojas de sedas e panos pobres ……………………………..... 8

Mercadores de lojas pequenas …………………………………………... 8

Mercadores de lojas pequenas pobres .............................................................. 4

Mercadores ricos de lojas grandes ......................................................................... 16

${ }^{24}$ VAlladares, Rafael: Banqueros y vasallos. Felipe IV y el medio general, Madrid, Ediciones de la Universidad de Castilla-La Mancha, 2002, pp. 31-56.

25 ERICEIRA, Conde de: Historia de Portugal Restaurado, vol. I.

26 ALMEIDA: Notícias da aclamaşão e de outros sucessos, pp. XIII-XIV.

27 OLIVEIRA: Elementos, tomo IV, p. 437.

28 ALMEIDA: Notícias da aclamaģão e de outros sucessos, pp. XVI-XVII.

29 Almeida: Notícias, p. XXI. 


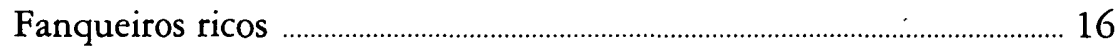

Fanqueiros de menos cabedal ......................................................................... 8

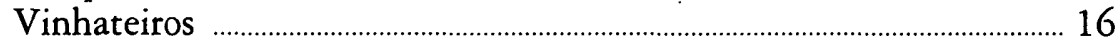

Vender vinho a vendagem e comida ............................................................ 4

Vender vinho a vendagem .................................................................................... 2

Oficiais com trato e meneio ............................................................................. 4

Oficiais afazendados .......................................................................................... 4

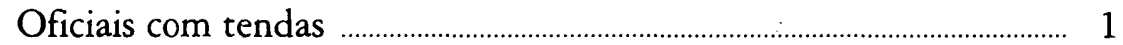

Oficiais sem tendas mas ricos ........................................................................ $\quad 4$

Oficiais sem tendas mas pobres ...................................................................... 1

Obreiros .............................................................................................. 1

Tendeiros de bons lugares .................................................................................. 4

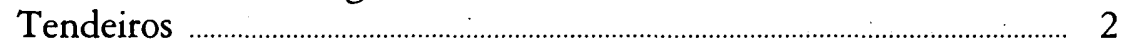

Tendas de fruta ........................................................................................... 1

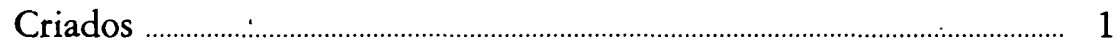

Os filhos e: filhas de sete anos para cima e. os criados pagariam segundo a cabeça de família estivesse avaliada. Lista longa, que só deixava de fora «os miseraveis, que vivem de esmola». Esses ficavam isentos. A cobrança e a arrecadação do tributo seriam feitas em cada freguesia por uma espécie de junta em que deviam figurar um fidalgo, um homem nobre, outro homem de negócio e um oficial mecânico, nomeados pela câmara e ainda um clérigo nomeado pelo bispo. Era serviço gracioso. Parecia que estes eram os meios «os mais iguaes, suaves e livres de inconvenientes» para que sem «molestia nem carga grande» se arrecadar o necessário à constituição do exército ${ }^{30}$.

Não parece que esta contribuição corresponda a décimas que fossem proporcionais e universais. Era uma imposição "por cabeças" ${ }^{31}$, muito rudimentar no seu cálculo, que se afastava de uma avaliação que se pudesse imaginar em rigor proporcional aos rendimentos de cada um dos tributados. Como que se tomavam as aparências por boas. Descobrem-se de imediato «difficuldades e incertezas grandes, que impossibilitam a execução do que tanto importa». Chamava-lhe o rei «assento e offerecimento» da cidade de Lisboa. Todos os demais oficiais das câmaras, fidalgos, cidadãos, homens bons, povos, prelados e eclesiásticos, de todas as "Cidades, villas, e Logares destes ditos meus Reinos» fariam o mesmo ${ }^{32}$.

Para organizar centralmente esta cobrança nomeou-se uma representação dos três corpos das cortes, a Junta dos Três Estados e Provimento das Fronteiras. Esta devia orientar os trabalhos de lançamento e recolha do tributo. A sua execução prática cabia a gente nomeada pelos municípios, que desempenhava

\footnotetext{
30 Oliveira: Elementos, tomo IV, pp. 422-427.

31 Oliveira: Elementos, p. 427.

32 Silva: Collecção, 1640-1647, p. 44.
}

Hispania, LXIV/1, núm. 216 (2004) 157-182 
um lugar central neste procedimento. Pelo rol dos fregueses - que seria talvez o da desobriga pascal - chamariam toda a gente, informando-se das rendas que cada um tinha ou do meneio e trato que exercitava, assentando tudo num livro. Em caso de dúvida podiam pedir informações. Os menos abonados, que deviam pagar apenas a vintena (5\%), declarariam quanto lhes cobravam pelo aluguel das casas em que moravam. Nas cidades e vilas teria a presidência um magistrado, a que se juntariam um fidalgo, um vereador, uma pessoa nobre ou cidadão e um popular, estes escolhidos pelas câmaras ${ }^{33}$.

Mas outros impostos indirectos iam sendo lançados sobre os povos, nomeadamente o real d'água que continuava a agravar o consumo de carne (ao arrátel) e de vinho (à canada) ${ }^{34}$. Tributo muito contestado, mas de simples execução. Por isso mesmo o preferido. A população de Lisboa era a mais castigada. Porque inicialmente - e antes da decisão das cortes de o lançarem em todo o Reino - prometera aumentar o real d'água para 5 réis por arrátel de carne e 7 réis por canada de vinho, enquanto as outras cidades e vilas viam os seus crescer apenas um real ${ }^{35}$. E as suas fortificações estavam bem necessitadas de intervenção. Sobretudo as terrestres. Lisboa resguardava-se pelo mar e pelo rio, pelas várias fortalezas que desde o tempo de $\mathrm{D}$. Sebastião foram sendo feitas ou refeitas. Mas não se podia esquecer o flanco terrestre - e a invasão de 1581 comandada pelo Duque de Alba mostrara como a cidade era vulnerável - e a defesa central pelo castelo de São Jorge.

Para fazer guerra era preciso dinheiro. E da abundância ou escassez dele dependia também ser a guerra ofensiva ou defensiva. A guerra ofensiva, levando as hostilidades ao território do inimigo implicava dispender somas muito mais elevadas. Mas a menos custosa manutenção de tropas na defensiva, aguardando ataques, fazia perder as vantagens da escolha estratégica. Havia que esperar decisões de outros, segundo os seus objectivos. Tanto mais desvantajoso agora quanto a monarquia de Madrid tinha que fazer face a várias frentes, com destaque para a Catalunha rebelada. Que lhe era mais urgente subjugar do que avançar na frente de Portugal. Na ordem das prioridades do monarca e do Conde de Olivares só depois de resolvida a questão catalã se volveriam os esforços bélicos contra Portugal. A proximidade da poderosa França assim o impunha ${ }^{36}$. Não avançar agora pondo a guerra no interior de Castela, para os restauradores portugueses, significava esperar por uma ofensiva, esperar o pior. Todavia, as disponibilidades da Fazenda e o estado do exército mais não permitiriam.

A cobrança do novo imposto das décimas não se revelou fácil. Ofereceram-se «tantos inconuenientes e difficuldades e responderão a tanto menos do em que se estimauão, que tem sido a falta do cabedal de se não hauer adiantado muito a

\footnotetext{
33 Oliveira: Elementos, tomo IV, pp. 439-441.

${ }^{34}$ ERICEIRA, Conde da: História da Portugal Restaurado, vol. I, p. 235; Oliveira: Elementos, p. 421.

35 Oliveira: Elementos, vol. V, p. 281.

${ }^{36}$ EllıotT: El conde-duque de Olivares. El político en una época de decadencia, p. 585.
} 
guerra e logrado a occasião presente de o fazer emquanto nosso enemigo se acha embaraçado e diuertido por outras .partes». Consultadas pessoas graves e doutas da nobreza de Lisboa e ouvidos os Vinte e Quatro, o rei determina que o pagamento será a décima parte do que cada um tem. É então que se começa a referir o subsídio de guerra como tributo das décimas. Sem contar com privilégios ou condições e qualidades. Ainda havia uma grande imprecisão em tudo isto.

Constatando as dificuldades de fazer cumprir o pagamento da décima, e porque queria que "negócio tão grande se encaminhe e assente com inteira noticia e Satisfação dos mesmos Reynos e Estados delles», o monarca torna a convocar as cortes para 15 de Setembro de $1642^{37}$. Nem todos concordariam com o pagamento. Mesmo depois dos aperfeiçoamentos introduzidos pelas cortes - «na forma em que nouamente se assentou e rezolueo»-, houve quem discordasse. $\mathrm{E}$ quem afixasse papéis contrários «em que se declaraua, que a contribuição se fazia sem ordem minha, E que nella erão os Pouos muito mais fintados, que a nobreza", escreve o rei ${ }^{38}$.

Para os municípios eram transferidas novas funções na política financeira de guerra. Cabia-lhes autorizar os recrutamentos, fornecer armamento quando dele dispusessem, assistir aos governadores militares e auxiliá-los no exercício das suas competências. Não menos importante, tinham que tratar da reparação dos castelos e fortalezas, muros, portas e postigos das povoações. Que sessenta anos sem arranjos tinham deixado em mau estado: porque em tempos de união não se justificava preparar defesas contra reinos com um monarca comum.

Nas cortes de 1642 a questão central tornou a ser a das décimas, agora com a experiência adquirida no primeiro ano de cobrança. Havia que aumentar o tributo, mas a grande questão, que precisou de mediações, foi a de se saber quanto pagava cada um dos corpos, «e não viesse a cair no povo, como menos poderoso, o maior peso. O Eclesiástico e a Nobreza uniram-se contra esta proposta» ${ }^{39}$. Por fim lá se chegou a um acordo por todos aceite. O que levou a que fosse reformado o regimento. Mas a cobrança das décimas continua a causar dificuldades.

O prolongamento da guerra na sua táctica deliberadamente defensiva não dava para amenizar a forte pressão fiscal. Mesmo assim, em fins de 1644 - depois da campanha vitoriosa daquele ano -, o rei aumentou o pedido que anteriormente fora feito. A cobrança só atingira o quantitativo de 1070 mil cruzados. Havia que completar os 1500 mil cruzados prometidos pelas Cortes. A câmara de Lisboa ainda sugere que se acrescente a décima da décima «não entrando n'ella nenhuma pessoa que trabalhe sem cabedal, vivendo só por jornal diario, será isto mais acceito e de menos oppressão aos povos» ${ }^{40}$. Mas acaba por

\footnotetext{
37 ALMEIDA: Notícias da aclamaşāo e de outros sucessos, p. XXIII; O Pôrto na Restauraşāo, pp. 90-91.

38 ALMEIDA: Notícias da aclamação e de outros sucessos, p. XXIV.

39 Ericeira, Conde da: Historia da Portugal Restaurado, vol. I, p. 408.

40 Oliveira: Elementos, tomo IV, pp. 563-565.
} 
anuir ao aumento, como Évora e Santarém. Seguiu-se-lhes Coimbra. A décima deve-se cobrar com rigor, as pessoas nomeadas seriam daquelas «de cujo zelo se possa fiar» ${ }^{41}$. Décima que seria acrescida. Para isso mandara o monarca: «subir a deçima do ecclesiastico ao justo, e que o mesmo mando fazer em algũas pessoas particulares, a que sou informado se lançou menos, do que deuem ${ }^{42}$. Aumenta-se no total cerca de 400 mil cruzados mais do que fora inicialmente assente. Para isso deveria cobrar-se mais a décima da décima (no total $11 \%$ ). Com condição que aos pobres nada mais fosse pedido ${ }^{43}$.

A Junta dos Três Estados não se fiaria muito das informações que the eram enviadas. Por isso o rei, ao querer saber «com toda a clareza, o dinheiro que rendem, em cada provincia, as decimas, e a quantidade de dinheiro que vae para cada uma d'ellas, para as despezas da guerra, a quem se entrega e como se dispende», pede à câmara de Lisboa que envie duas pessoas «que servem ou servirão» na Casa dos Vinte e Quatro para irem pelas províncias ver os «livros, contas e papeis» e lhe darem verdadeira relação do que se passava ${ }^{44}$. É notável (e estranho) que dos mesteres de Lisboa saia a gente de confiança para uma tal inspecção. Tratar-se-ia de atenuar as acusações de que só o povo pagava o que devia? Não é impossível. Mas não parece que esta missão tenha sido efectuada. A verdade é que o quantitativo contratado não chegava e se tornava indispensável aumentá-lo. Manda então el-rei que se consigam mais 400 mil cruzados $^{45}$.

A guerra continuava, e não apenas nas fronteiras de Castela. No Brasil a Companhia das Índias Ocidentais alargara o território conquistado, ofensiva a que também era preciso responder. Mesmo depois das tréguas de 1641 instalara-se ainda em Angola e em São Tomé. Por tanta despesa a que acorrer, e para melhorar o lançamento das décimas, o rei convoca de novo as cortes, o que ocorreu a 28 de Dezembro. Em parte fora forçado a fazê-lo porque a câmara de Lisboa era de parecer de que se não deviam prorrogar as contribuições sem essa reunião ${ }^{46}$. E aí continua a evidenciar-se a dificuldade de cobrar os 1.700 mil cruzados anteriormente assentados. Pelo melhor, tinha-se conseguido atingir 1.050 mil cruzados. Para completar a verba necessária ter-se-ia que aumentar os usuais. Mas logo o juiz do povo de Lisboa apresenta objecções, que são atendidas. Melhor era repartir «o que faltaua por esta Cidade, e seu termo, e pelas Comarquas do Reyno, e eccleziastico». Procede-se logo à fixação do que a cada uma das entidades caberá pagar anualmente ${ }^{47}$.

\footnotetext{
41 Oliveira: Elementos, tomo IV, p. 598.

42 Almeida: Notícias da aclamaģão e de outros sucessos, pp. XXXVII-XXXVIII.

43 SILVA: Colleç̧ão, 1640-1647, p. 257.

44 Oliveira: Elementos, tomo IV, pp. 612-613.

45 SILVA: Collecção, 1640-1647, p. 273.

46 Oliveira: Elementos, tomo VI, p. 174.

47 ALMeIDA: Notícias da aclamaşão e de outros sucessos, pp. LVII-LX.
} 
Alenquer com as terras da Rainha

Almada

30433222

Aviz

Beja

2838141

12457190

18301781

Braga

4872655

Barcelos

11381277

Bragança

8346044

Crato

5120719

Coutos de Alcobaça

2933333

Coimbra

29333333

121017695

Campo de Ourique

9038867

Castelo Branco

11764111

Chaves

3056139

Esgueira

16830527

Elvas

2978605

Évora

27972221

Guarda

Guimarães

18554409

26158974

Lamego

22714437

Lagos

7243092

267329077

Leiria

11034771

Miranda

5837879

Ourem

Porto

3238888

Portalegre

26914035

8416658

Pinhel

Tavira

13357254

6145566

9485682

Torre de Moncorvo

Tomar

Santarém

20611109

26500000

399870919

Setúbal

22360522

Viseu

18470095

Viana

Vila Viçosa

Freguesias de Lisboa

Freguesias do termo

2843288

53460000

15411110

1472221

Câmara de Lisboa

24783332

Juros, tenças e ordenados de Lisboa

564815850

Hispania, LXIV/1, núm. 216 (2004) 157-182 
Ilhas

\section{Eclesiásticos}

Arcebispado de Lisboa

8500000

Arcebispado de Braga

22900221

Miranda

2402233

Algarve

1947059

Porto

5863275

Coimbra

6123610

Lamego

4458665

Viseu

4070888

Leiria

1678.610

Guarda

3268888

Évora

8619888

Portalegre

636617

Elvas

Inquisições do Reino

1079301

700000

650076092

\section{Religiões}

Província de São Francisco da Cidade

1784665

Província de São Francisco do Algarve

736692

Cónegos regulares de Santa Cruz

Religião de São Bernardo

Padres da Companhia

2974448

4759113

Religião de São Bento

3569332

Religião da Trindade

2974448

449660

Religião de São Domingos

477222

Religião de Santo Agostinho

1189775

736110

Religião do Carmo

670727554

Religião de Santo Elói

1487221

Religião de São Jerónimo

588888

220830

220830

Religião de São Paulo

44167

Terceira Ordem de São Francisco

4174221

220830

223352

892332

1189775

680000000

Hispania, LXIV/1, núm. 216 (2004) 157-182 
Estes 1700 mil cruzados sairiam da décima e usuais, de que se exceptuaria o pão, vinho, carne, azeite, calçado, e panos baixos. Eram artigos de que os pobres precisavam. Os 450 mil cruzados mais sairiam do real d'água de Lisboa e do reino, do novo direito da chancelaria, do imposto sobre as caixas de açúcar, dos bens confiscados dos ausentes e do rendimento da Casa de Bragança. Reafirma-se, uma vez mais, que «a decima se devia lançar mui egual e ajustadamente sobre as rendas de todas as pessoas dos trez estados, do clero, nobreza e povo, sem excepção alguma». Parece que havia algumas comunidades religiosas que tinham conseguido escapar ${ }^{48}$. Mas não se queriam excepções, neste esforço de guerra. O próprio embaixador do rei de França, mesmo tendo açougues privativos, tinha que pagar os direitos fixados ${ }^{49}$.

A fiscalidade não pode ser vista apenas do lado das receitas. Do lado das despesas as desconfianças também eram muitas. Era preciso saber-se quanto se gastava e como se gastava, "para que ao povo seja notorio se gasta tudo na defensão do reino" ${ }^{50}$. O que não acontecia. Porque os povos viam "com seus olhos divertir o dinheiro em gastos e despezas desnecessarias de ordenados, conducções e carretos do dinheiro das provincias [...], salarios que de novo se constituiram aos superintendentes das decimas e outros officiaes e ministros, cambios de assentistas e outras cousas». E concluem: «o dinheiro que falta não é por os povos não pagarem e contribuirem com o necessario, e mais do que podem em tempos tão apertados, senão porque se diminue com estas despesas escusadas, com o que vem a faltar para as necessarias». A câmara de Lisboa não entendia, ou fazia que não entendia, a forçosa ampliação da máquina burocrática que a multiplicação dos tributos implicava. Mas sem dúvida que tinha razão ao chamar a atenção do rei para que «tornar a bulir em novo acrescentamento e contribuição é renovar as feridas e revolver os humores, cousa muito perigosa em taes tempos, estando já os povos quietos com esta contribuição" ${ }^{51}$. As décimas estavam aceites sem dificuldade, entradas nos hábitos de pagamento, não era boa a política de ir buscar mais somas a outros tributos novos ou renovados.

Continuava a ser sempre um escolho o que se passava pela banda dos clérigos. Para completar o 1700 mil cruzados prometidos nas cortes de 1645 havia que encontrar meios de actuação. A câmara de Lisboa não deixa de lembrar que Sua Majestade devia «mandar ajustar o ecclesiastico, sem se lhe admitir o donativo nem outras composições, por se entender que, contribuindo-se com egualdade entre todos os trez estados, seria a falta de muito menos consideração do que. se representava». Nisto se trabalhava há sete anos sem se conseguir ajustar. Devia tratar-se sempre dos «lançamentos das decimas com toda a egualdade, e de pôr os preços dos fructos em seu justo valor». Ao povo de Lis-

\footnotetext{
48 Oliveira: Elementos, tomo V, p. 3.

49 SIlva: Colleç̧ão, 1640-1647, p. 274.

so Oliveira: Elementos, tomo V, p. 65.

s1 Oliveira: Elementos, tomo V, pp. 144-148.
} 
boa não convinha que se fosse buscar o que faltava aos usuais. Mas em 1646 tinham ficado as décimas abaixo do previsto em 700 mil cruzados, e o rei não via outra maneira de conseguir a soma que era indispensável para a guerra. E o rei também se mostrava decidido a que os eclesiásticos «entrassem com toda a egualdade» porque tinham que "dar exemplo aos mais vassallos assim por a causa ser comum a todos, como por estarem isentos dos mais encargos de guerra, com tanta parte que possuem dos bens do reino». Também sobre os poderosos laicos se devia lançar inteiramente a décima, para «com isso cessar o escandalo, que resulta d'elles não contribuirem com o que devem" ${ }^{52}$. Estas falhas vão obrigar o monarca a condicionar a admissão de julgadores impedindo os que não tenham certidão de bem terem cumprido as suas obrigações nas cobranças. Descuidos e omissões eram suficientes para impedimento de exercício dos cargos. As certidões seriam passadas pela Junta dos Três Estados ${ }^{53}$.

Desembargadores são enviados pelas comarcas para com os oficiais das câmaras e ministros das juntas tratarem do lançamento, obviando com isso às queixas dos vassalos ${ }^{54}$. Não faltavam as rectas intenções. Faltavam era meios de actuação numa sociedade que procurava furtar-se à igualdade e à proporcionalidade tributárias. E onde qualquer pretexto servia para iludir pagamentos: era o caso de tesoureiros, almoxarifes e recebedores que ficavam devedores à fazenda real mas que entregavam bens próprios por essas dívidas. Bens que não valiam o que tinham recebido em bom dinheiross. Nas cortes de 1646 concluiuse que ainda estava bastante quantia por arrecadar. Em 1646 teriam faltado 650 mil cruzados, tendo rendido 1050 mil e em 1647 se esperava que houvesse uma «falta muito consideravel», devendo atingir 1700 mil cruzados. A dificuldade estava na repartição, pelo que $o$ rei ordena à Junta dos Três Estados que soubesse com certeza o que tinha importado e providenciasse para que se atingisse a soma de 1700 mil cruzados. E um novo regimento das cobranças se publica; em 10 de Dezembro de $1646^{56}$.

Aparentemente as coisas estavam bem encaminhadas para sustentar uma guerra que já então se adivinhava muito longa. Portugal não fora admitido à mesa das negociações do Tratado de Münster, por mais que os diplomatas de D. João IV se tivessem esforçado por conseguí-lo57. O que desde logo significava que a monarquia filipina não admitiria tão cedo, e sem provas provadas de derrota no domínio militar, negociar o abandono de um reino que herdara. $O$ que teria obrigado a aumentar a décima. Mas sempre se receia proceder a acrescen-

\footnotetext{
52 Oliveira: Elementos, tomo V, p. 66.

33 SiLva: Colleç̧ão, 1648-1656, p. 77.

54 Silva: Colleç̧ão, 1640-1647, p. 339.

ss SILVA: Coleç̧äo, pp. 312-313.

56 SILVA: Colleç̧ão, pp. 339-341.

57 PRESTAGe, Edgar: As relações diplomáticas de Portugal com a Fraņ̧a, Inglaterra e Holanda de 1640 a 1668, trad., Coimbra, Imprensa da Universidade, 1928, pp.19-29.
} 
tos. Por isso o rei determina que a Junta dos Três Estados mande fazer com moderação a cobrança do acrescentamento ${ }^{58}$. Mas não faltavam as desconfianças.

Em 1649 continuavam os povos a queixar-se «de se não contrebuir pellas Religiões e outras comonidades com a igualdade que se prometeo $\mathrm{E}$ assentou em cortes, tendo elles sobre sy os mais encargos da guerra de que o estado ecclesiastico se acha liure». Reunida a Junta dos Três Estados, verificou-se que «não so hauieis faltado em lançar em uossa jurisdição o que the coube pella reparticão no acrecentamento de decima, como se contrebue no secular, mas que ainda deixaueis de pagar o com que de antes contrebuhieis na forma dessa Relacão». Manda o rei que tratem «logo da cobrança». O ser o «lançamento com toda a igualdade» era razão imperiosa para que todos pagassem ${ }^{59}$.

No entanto, em 1649 as cortes não se reunem. A peste no Algarve e a estagnada situação militar - que obrigava à manutenção das décimas com o acrescentamento - não aconselhavam a reunião, que esteve marcada para Tomar. Em especial a câmara de Lisboa insiste com o monarca para que suspenda a ordem emitida. Tudo ia ficar na mesma, pelo que não era necessário fazer-se tanta despesa nem arriscar contágios. E continuou a cobrança, sem acrescentamentos nem novidades. As câmaras do reino prontificaram-se a continuar a contribuição das décimas, mesmo que fosse necessário acrescentá-las. Era «o mais prompto effeito" ${ }^{60}$. Mas o rei, que jubilosamente aceita a dispensa de cortes, reitera que muito deseja «vel-os livres das contribuições que pagam ${ }^{61}$. Desejos que ainda distam muito de se poder satisfazer. Porque as desconfianças aumentam, sendo necessário verem-se nas câmaras os livros da arrecadação das décimas para se ajustarem os quantitativos pagos ${ }^{62}$.

Em 1651 a Junta dos Três Estados representa ao rei que «a cobrança das décimas estava muito atrazada, e devendo-se dellas, nesta Côrte, e Commarcas do Reino, quantias consideraveis, que se não pagaram dos lançamentos dos annos passados, e que desta dilação nascia a grande falta que havia no provimento das Fronteiras, e se podia seguir della maior damno, por não haver outra consignação para a despesa da guerra e defensa do Reino". A argumentação é sempre a mesma. Mas para que haja encaixe de maior quantia, em Lisboa também passam os letrados a superintender na matéria, como já ocorria nas cabeças das comarcas. Os que tivessem servido nestas ocupações de lançamento e cobrança, na corte como no Reino, passavam a gozar de alguns privilégios ${ }^{63}$. Era a forma de recompensar incómodos e trabalhos. Pessoas que deviam ser de zelo e inteireza para que «a estimação das fazendas e cabedaes» fossem bem executadas ${ }^{64}$.

\footnotetext{
58 SILVA: Colleç̧ão, 1640-1647, p. 314.

59 ALMEIDA: Notícias da aclamaçäo e de outros sucessos, p. LXXIII.

60 Oliveira: Elementos, tomo V, pp. 161 e 167.

61 Silva: Collecção, 1648-1656, p. 45.

62 Silva: Coleç̧äo, 1648-1656, p. 57.

63 Silva: Collecção, 1648-1656, pp. 89-90.

${ }^{64}$ SILVA: Collecão, p. 93.
} 
A tributação extraordinária ia-se instalando nos hábitos e práticas da população. A própria guerra se tornava normal. $\mathrm{O}$ grande choque das décimas ia sendo esquecido, ou pelo menos perdia o vivo da novidade. Algumas omissões são apontadas, que relevam dessa normalidade ${ }^{65}$. Essa estagnação da guerra que leva a que sempre se procure manter estável a fiscalidade, por mais que as necessidades pudessem exigir aumentá-la. O que é preciso é ir encontrando dinheiro para satisfazer as despesas com a defesa, em tempos «em que por não chegarem as contribuições ao promettido em côrtes desamparam os soldados as fronteiras, com grande prejuizo e perigo do reino». Caída Barcelona em 1652, tornava-se fácil prever que as tropas de Felipe IV se virariam para a conquista de Portugal. Como dizia logo de início o Marquês de Montalvão, "pois hé certo que cessando as armas em Catalunha, por vencimento ou por compozição, lhes fica o primeiro cuidado da recuperação de Portugal» ${ }^{66}$. El-Rei de Castela "desembaraçado dos inimigos que até agora o divertiam, armava poderosamente contra este reino, por mar e por terra»:

Continuavam a faltar 500 mil cruzados para completar a verba anual que fora aprovada em cortes. E havia que providenciar a defesa de Lisboa. O rei vende património da coroa, «a nobreza servia com o quinto dos bens da coroa que possue, e as ordens militares de Christo, Santiago e Aviz com o quinto do rendimento das commendas e mais bens». Setúbal contribuía com um imposto sobre o sal, Sesimbra com um imposto sobre o pescado. Era indispensável que Lisboa contribuísse com «algum effeito sufficiente» para se fortificar a cidade e se pagarem quatro mil infantes, oitocentos cavallos e uma armada competente». O tributo que parecia «mais fácil na cobrança e de maior rendimento, era impôr direito no pão que gasta esta côrte e seu termo». Imposto em que entravam também os donatários e comendadores». Assim foi decidido, devendo pagar-se «um vintem em cada alqueire de trigo e dez réis em toda a outra sorte de pão, entrando cevada». Isto para pão vindo do reino. Das ilhas ou de fora do reino pagaria a 10 réis o alqueire de trigo e 6 réis o de cevada ou de segunda. Queria-se que houvesse «acceitação e contentamento geral de todos» ${ }^{67}$. Pode imaginar-se o contentamento! Mas a ideia de que todos pagassem parece aceite, contraditoriamente com uma sociedade estamental como era a portuguesa de Seiscentos.

Só que o juiz do povo e os eleitos da Casa dos Vinte e Quatro não convieram na tributação do trigo. Houve reunião na Secretaria de Estado durante dois dias (5 e 6 de Fevereiro de 1653) e ficou decidido que a imposição passasse a ser sobre o azeite que entrasse na cidade e termo, meio tostão em cada cântaro por entrada, um tostão por saída. Do sal pagar-se-ia quatro vinténs por cada moio. Far-se-ia estanque da aguardente e impor-se-ia a dízima na chancelaria de todos os juízos, excepto os dos órfãos. O açúcar que não pagasse outros im-

\footnotetext{
65 Oliveira: Elementos, tomo V, p. 323.

66 Pereira, Ângelo: «O exército da Restauração», in Ocidente (Lisboa), VIII (1940), p. 18.

67 Oliveira: Elementos, tomo V, pp. 389-395.
} 
postos devia passar a ter uma carga de quatro vinténs por arroba. Eram estes tributos «os mais eguaes e os que menos carregam o povo». $\mathrm{Na}$ reunião ainda se falou no papel selado. Porém «disseram todos que se não conformavam com este meio por ser de Castella, cujos exemplos se não deviam imitar" ${ }^{68}$. Era suficiente para afastar o efeito. A câmara, ao tomar conhecimento do novo acordo, adverte que não tinha havido "consentimento do clero»69. Era um bom aviso.

Mas ainda era pouco para se alcançar os cem mil cruzados. Pelo que o rei deita mão dos rendimentos da alfândega e das Sete Casas. Assim se somavam os 40 contos, ou 100 mil cruzados. Destes direitos não será escusa pessoa alguma [...] pois sendo a causa comum é justo que todos, sem excepção, concorram para ella egualmente» ${ }^{70}$. Dois dos mesteres que participaram nesta busca de receitas acabaram por isso por ser excluídos e expulsos da Casa dos Vinte e Quatro, por excederem a procuração que levavam. Ao que parece, teriam concordado com o lançamento sobre o pão $0^{71}$. Mas nada de papel selado ${ }^{72}$. A sua origem castelhana dá-lhe uma má fama invencível...

A morte do Príncipe D. Teodósio obriga D. João IV a convocar cortes para jurar como herdeiro o Infante D. Afonso. Iniciaram-se em Lisboa, a 22 de Outubro de 1653. As cortes aceitam continuar com as imposições. Assim tinha que ser. Ficou assente que o reino contribuiria com 1300 mil cruzados por ano, através da décima, e que 100 mil cruzados mais ficariam em depósito para acudir a qualquer invasão inimiga. Esta soma seria junta pelo pagamento de um quartel da décima $(2,5 \%)$, que se cobraria se houvesse "provavel noticia» de ameaça. $O$ estado eclesiástico também se comprometeu a pagar $150 \mathrm{mil}$ cruzados. Assim se tinha resolvido. E será recordado ${ }^{73}$. Tudo constará do novo e muito pormenorizado Regimento das Décimas, publicado a 9 de Maio de 1654 e em seguida impresso, para que ao conhecimento de todos viesse ${ }^{74}$.

Mais penalizada ainda se sente agora a capital, cuja defesa se prepara. Os novos impostos, para providenciar a sua defesa, recebem regimento em 10 de Outubro de $1654^{75}$. Com D. João IV a previsibilidade dos pagamentos era total, a menos de uma emergência que obrigasse a um acrescentamento, mas mesmo assim discutido e aprovado. Foi o que aconteceu com o apoio à França, a troco de uma sempre ambicionada liga formal: parte dos novos impostos, que tanto penalizavam a população, vão ser de imediato destinados a esse fim. Esperava-se que com bom efeito militar, mantendo as duas frentes contra Castela, pelo que acabado de se cobrar este socorro, as novas contribuições deixariam

\footnotetext{
68 Oliveira: Elementos, tomo V, pp. 395-397.

69 Oliveira: Elementos, tomo V, p. 397.

70 Oliveira: Elementos, tomo V, pp. 417-420.

71 Oliveira: Elementos, tomo VI, pp. 4-9.

72 Oliveira: Elementos, tomo V, p. 422.

73 OLIVEIRA: Elementos, tomo VI, pp. 170-171 e 305-306.

i4 Silva: Colleç̧ão, 1648-1656, pp. 302-311.

75 Oliveira: Elementos, tomo V, pp. 496-502.
} 
de pagar-se. A menos de continuar a guerra com Castela e a necessidade de fortificar Lisboa ${ }^{76}$. O que iria acontecer.

Entretanto algum tanto poderia ter melhorado a situação da fazenda régia. Reconquistado o Recife em Janeiro de 1654 não tardou a que mais açúcar passasse a ser despachado no reino. Isto apesar do conflito com a Inglaterra que ia deitando tudo a perder, por ter a barra do Tejo sido bloqueada pelas forças do Parlamento britânico. Mas poucos anos passados já se podia dizer que o quinto dos açúcares "é o maior rendimento do novo imposto»77.

Não vai ficar por aqui essa aplicação. Em 17 de Maio de 1656 o rei manda que se entreguem mais 60000 cruzados do cofre dos novos impostos para se continuar o apresto da armada. Duvidou o juiz do povo fazê-lo, sem consultar a Casa dos Vinte e Quatro. Convieram todas as bandeiras em que isso se não devia fazer. As novas contribuições podiam destinar-se à armada da costa. Mas não para esta que se preparava, de defesa do comboio da Companhia do Brasil: deveria o quantitativo necessário sair do consulado. Apesar da resistência dos mesteres, a câmara acaba por concordar com essa aplicação ${ }^{78}$. D. João IV entende a objecção. E promete que se não for para defesa contra a armada inglesa determinará a reposição da verba ${ }^{79}$. Pelo mesmo motivo protesta o juiz do povo de se estarem a pagar os soldados de São Julião da Barra com verbas dos novos impostos ${ }^{80}$. Os mesteres preferiam que estas despesas extraordinárias e inesperadas fossem satisfeitas com os rendimentos dos quintos dos bens da coroa, pois que "a nobreza assim foi contente e o prometteu» ${ }^{81}$. Mas difícil era que os bens da coroa retornassem, por morte dos que os detinham ${ }^{82}$.

As dificuldades cresciam e os recursos do reino minguavam. As décimas começavam a ficar secundarizadas perante a premência que forçava a deitar mão de quaisquer recursos, quer novos quer tradicionais, como as alfândegas e os impostos sobre o consumo. Muito em especial o real d'água sobre a carne e o vinho que a câmara de Lisboa concedera como donativo e que se eternizava quase como se fosse um tributo ordinário. O novo regimento de 1656 , tornava mais rígida a fiscalização sobre o seu cumprimento das imposições, o que desagrada profundamente aos Vinte e Quatro ${ }^{83}$. Mas as coisas iriam ainda piorar.

Morto D.João IV em Novembro de 1656 é o novo regimento do real d'água que vai ser imposto. Ainda houve alguma espera, mas alguns meses passados a publicação acontece. As preocupações parecem mudar, e o processo encontra-se

\footnotetext{
76 OliveIRA: Elementos, tomo V, pp. 526-527; tomo VII, pp. XLI-XLIII.

77 OLIVEIRA: Elementos, tomo VI, p. 140.

78 Oliveira: Elementos, tomo V, pp. 555-591.

79 Oliveira: Elementos, tomo V, p. 593.

${ }^{80}$ Oliveira: Elementos, tomo V, pp. 614-615.

81 OLIVEIRA: Elementos, tomo VII, pp. LXV-LXVI.

82 Silva: Collecção, 1648-1656, p. 82.

83 OliveIRA: Elementos, tomo VII, pP. LXVI-LXX.
} 
nas mãos do secretário de Estado Pedro Vieira da Silva, um eclesiástico ${ }^{84}$. Há que suspeitar que as preocupações com a boa distribuição do período anterior deixam de ser prioritárias. Interessa, sobremaneira, aumentar as receitas, mesmo que isso implique penalizar os lavradores do termo de Lisboa que até então nunca tinham pago o real d'água. Parece que não há, agora, os mesmos escrúpulos na actuação fiscal. Não se estranha, nesta viragem aristocratizante, que os vereadores da câmara de Lisboa peçam e consigam ver os seus ordenados aumentados, ficando equiparados aos ministros dos mais tribunais, com 300 mil réis de ordena$\mathrm{do}^{85}$. A regente bem lhe convinha também tê-los do seu lado.

Porque a câmara e a população de Lisboa continuam a ser financeiramente as mais penalizadas. A qualquer aflição da fazenda, é à câmara da capital que se recorre. Em 1658, sendo necessários duzentos mil cruzados para o velho propósito da liga com a França, a rainha determina: «hei por bem que o senado da camara, escolhendo o meio mais breve, egual e seguro em que se possão lançar e cobrar, os imponha e execute» ${ }^{86}$. E pouco depois, vendo que as receitas do azeite e do sal, como da aguardente, eram recusadas pelo reino, a regente decide levantar os novos impostos nesses produtos. Logo a câmara de Lisboa, ouvidos os Vinte e Quatro, recusa. Com boas razões. Os novos impostos de 1657 tinham resultado de um contrato entre o rei e a câmara, contrato entre pessoas, que como tal tinha que ser cumprido por ambas as partes. À tentativa da coroa de deixar de cobrar uma parte do contratado, a câmara reage e a regente acaba por deixar correr a cobrança dos novos impostos. Todos ${ }^{87}$. Porque o contrato não podia ser fragmentado. Claro que o quinto dos bens da Coroa se cobrava muito mal. Mas a câmara de Lisboa vê fugir-lhe essa competência, que passa para a Junta dos Três Estados ${ }^{88}$. A aristocracia já contribuía com as suas prestações militares; ao povo cabia pagar.

Parece perdida uma orientação geral e global para o financiamento da guerra da restauração: as necessidades obrigavam «a se usar de todos os meios de acrescentar o dinheiro tão necessário para a guerra» ${ }^{89}$. Antecipações, empréstimos, de tudo se faz, sem considerações ou justificações. Deixam de se buscar os meios mais suaves para evitar o castigo da população. Havia míngoa de recursos, havia que encontrá-los onde quer que estivessem. O endividamento da Coroa arrastava consigo o da câmara de Lisboa, a mais rica do reino, a que estava mais a jeito pela proximidade ao trono, a que menos protestaria porque os seus presidente e vereadores eram de nomeação régia. Mas sempre a câmara zelava por que na sua contabilidade não se instalassem confusões. Distinguia sempre as verbas pelas suas proveniências, procurava jogar com antecipações e empréstimos de modo a que não se desviasse o destino das somas arrecadadas.

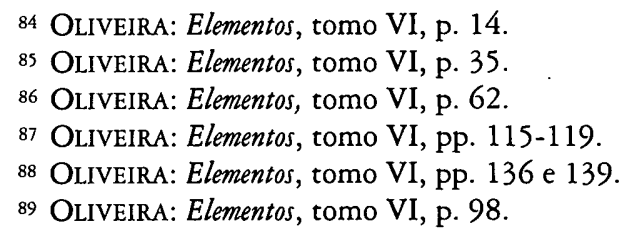


Não eram as décimas esquecidas. Em 1658 são mesmo acrescentadas de um quarto ${ }^{90}$. Quantitativo indispensável para a guerra, acontece que as receitas cobradas têm aplicação nas áreas de conflito, pelo que faltam no conjunto do reino. Em 1659 a regente declara que obrigaram «os apertos d'Entre-Douro e Minho a largar-lhe, para se despender em sua defesa, toda a decima que se cobrava naquella provincia, que era de consideração; e porque falta outra tanta somma á provincia do Alemtejo e ás mais do reino, e é forçado suppril-a por outros effeitos, que não ha em minha fazenda, nem na junta dos trez estados, desejo satisfazel-a pelos novos impostos, que esta cidade impoz sobre si para sustentação do terço e fortificação d'ella» ${ }^{91}$. Ainda e sempre as décimas mostravam-se quantiosas e indispensáveis ao esforço de guerra. Mas em momentos de aflição tudo se esquecia. Sitiadas as praças de Elvas, Monção e Salvaterra manda-se que as câmaras do Reino acudam com toda a eficacia pelas suas «rendas, bens de raiz e crescimos das sisas ${ }^{92}$. Não era momento para discutir. Vendem-se juros sobre as rendas das Casas de Bragança e de Vila Real93.

$O$ poder real tenta chamar aos conselhos e juntas que tem perto a competência fiscal. Nem sempre com êxito. Quando pretende que não seja o senado de Lisboa a tomar as contas do real d'água mas o superintendente da contadoria geral de guerra, ofende a câmara. E esta recusa ${ }^{94}$. Não seria conveniente que se soubesse o que rendiam esses impostos? Há uma tensão entre o Senado e a Coroa. A Casa dos Vinte e Quatro queixa-se de que se assentam os novos impostos «sem se dar noticia á câmara d'esta cidade e Casa dos Vinte e Quatro, como sempre foi estylo e se fez» ${ }^{95}$. A realeza procura libertar-se da constante vigilância da câmara em matéria tributária. E muito em especial dos representantes dos mesteres. Que de quando em vez se arrogavam poderes que não tinham. Por isso logo em 1642 o rei declarou que «a nenhuma pessoa, nem Ministro, e muito menos ao Juiz do Povo, é lícito embargar as leis geraes» ${ }^{96}$.

As respeitosas relações anteriores, do tempo de D.João IV, parecem próximas de chegar ao fim. O grupo governante que rodeava a rainha regente $\mathrm{D}$. Luísa não lidava com a câmara da cidade tão cuidadosamente como o rei defunto. Câmara que lhe era obediente em extremo e que sem dificuldade seguia as determinações que lhe chegavam. Porém desde que dentro do que as leis e as práticas a tinham acostumado.

Junto da regente encontram-se os Condes de Odemira e Cantanhede, o secretário de Estado Pedro Vieira da Silva e Gaspar de Faria Severim. Mais uns quantos ajudavam a rainha na chamada Junta da Noite: o Marquês de Niza,

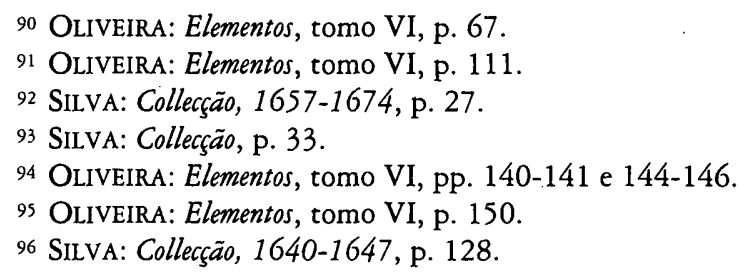


Pedro Fernandes Monteiro, o conde de São Lourenço e Frei Domingos do Rosário $0^{97}$. Pequeno grupo, dispondo de amplos poderes, que não mantém uma relação cordial com os poderes institucionais. Em 1660 o juiz do povo apresenta queixa na câmara de que o assento das cortes de 1653 ainda não chegara, nem o novo regimento das décimas. Tendo saído impresso, nem uma cópia fora enviada aos Vinte e Quatro. Pior: os dias passados a regente mandara «executar novos tributos, com o titulo de sua regalia, sem dar conta aos povos e sem os querer ouvir nem mandar deferir a uma nossa consulta sobre esta materia, e que agora novamente acrescenta pelas freguezias d'esta cidade outra quarta mais da decima, alem da do ano passado, com que vem a ser decima e meia, sem se escrever ás camaras e convocar os povos' ${ }^{98}$.

A leal relação do governo com a câmara parece deteriorar-se. Disso se queixa a câmara, em 1660: «mostra Sua Majestade que não fia d'elles esta mesma conservação e obediencia a seu serviço, de que se segue que o povo e as outras cidades e villas, faltando-lhes o exemplo da camara de Lisboa, frustrados os bons e sãos intentos com que procedem, titubiam, pasmam e não sabem acertar com o que mais lhes convêm». A regência não terá contado com os ministros mais habilidosos. Que por isso na autoridade jogam tudo. Sem contar com a necessidade de se explicarem as soluções aplicadas. E sem quererem reunir cortes para o efeito de aprovação, por mais que os Vinte e Quatro de Lisboa nisso insistissem. Mas o que importava ao governo era «acudir a esta necesidade, tão grande e tão imminente, que não soffre seu remedio a menor dilação»"99.

Em geral a décima já seria considerada relativamente fácil de cobrar, excepto na parte que cabia aos poderosos. A habituação instalara-se. Em 1660, em aflições, a coroa manda cobrar mais um quartel da décima por todo o reino ${ }^{100}$. Subia assim a décima a $15 \%$. Era uma escalada no aumento da imposição porque se previa possível cobrá-la. Os Vinte e Quatro não querem consentir nisso, pondo como alternativa que «haja egualdade das contribuições em todo o reino e cuidado na cobrança». Sobretudo, fundamenta a recusa por não haver «resolução de cortes» ${ }^{101}$. Desta vez a situação devia ter sido considerada como conflitual, pois a realeza determina que se pague, mas lisongeia a câmara de Lisboa e declara que para «se cobrar a decima dos poderosos, que a devem, tenho mandado passar as ordens necessarias» ${ }^{102}$. Afinal acontecia que dos quintos dos bens da coroa nem a Casa de Vila Real, nem a de Castelo Rodrigo, nem a de Bragança e

\footnotetext{
97 RAPOso, Hipólito: D. Luísa de Gusmão, Duquesa e Rainha, Lisboa, Empresa Nacional de Publicidade, 1947, p. 243.

98 Oliveira: Elementos, tomo VI, pp. 170-177.

99 Oliveira: Elementos, tomo VI, pp. 175-177.

100 Oliveira: Elementos, tomo VI, p. 188.

101 Oliveira: Elementos, tomo VI, p. 190.

102 OliveIRA: Elementos, tomo VI, p. 191.

Hispania, LXIV/1, núm. 216 (2004) 157-182
} 
a de Aveiro estavam a pagar. Não se sabia porquê. A negligência de alguns magistrados faria também com que se cobrasse menos do que era justo ${ }^{103}$.

Têm a câmara de Lisboa e os Vinte e Quatro também que estar atentos para evitar a desvalorização da moeda que se preparava e a que conseguem obstar. Mas a realeza estava demasiadamente aflita para atender a qualquer objecção: «a falta de dinheiro a tudo obriga» é a resposta concisa ${ }^{104}$. E não chegam advertências, consultas e pareceres para modificar o que estava decidido. Amplia-se mesmo a todo o reino o novo imposto dos azeites que estava lançado em Lisboa. E oito réis em cada canada de vinho no real d'água da capital ${ }^{105}$.

Quase ao mesmo tempo, em 24 de Dezembro de 1660, conhecia-se o regimento do papel selado, que se converteria em motivo de alterações populares ${ }^{106}$. Logo a ideia ser proveniente de Castela não tornava a novidade simpática - e por isso mesmo já antes fora recusada. Mas a própria violência da imposição - que não passara por aprovação em cortes - motiva para o protesto. Enquanto em Lisboa a câmara e os Vinte e Quatro procuram ganhar tempo e fazer ver ao governo que seria melhor buscar outros meios, o governo afirma que o rei tem pleno direito para impor tributos sem a intervenção dos povos ${ }^{107}$. Era a exaltação do poder monárquico que não acontecera com D. João IV, sempre cuidadoso na forma de lidar com os povos. Enquanto uns procuram sobrestar na aplicação da nova forma de tributo ${ }^{108}$, outros protestam com motins. Foi o que aconteceu no Porto. O papel selado existente foi queimado ou rasgado. Levou uns meses até que o imposto fosse aceite. Mas a Casa dos Vinte e Quatro do Porto foi extinta. E alguns dos amotinados foram castigados ${ }^{109}$.

Em 1661 antevê-se o aumento de dificuldades. Felipe IV alcançara uma «paz universal» e ficava de mãos livres para atacar Portugal, e só Portugal. No Conselho de Guerra sabia-se que isso ia acontecer ${ }^{110}$. Lisboa seria especialmente visada, «por ser o intento do inimigo comettel-a com uma armada poderosa, ao mesmo tempo que o fizer com seus exercitos pelas fronteiras" ${ }^{111}$. Os meios de que a coroa se podia valer estavam quase esgotados. E todos os seus esforços se iriam orientar no sentido de prevenir os meios militares para a ofensiva que não faltaria. Neste aperto havia ainda que apelar para uma contribuição voluntária.

\footnotetext{
103 OLIVEIRA: Elementos, tomo VI, pp. 207-209.

104 Oliveira: Elementos, tomo VI, p. 194.

10s Oliveira: Elementos, tomo VI, pp. 230-232.

106 DiAS, João José Alves: «Para a história dos impostos em Portugal. O papel selado no século XVII", in Ensaios de História Moderna, Lisboa, Editorial Presença, 1988, p. 203; SILVA: Colleç̧ão, 1657-1674, pp. 50-58.

107 OliveirA: Elementos, tomo VI, pp. 203-204.

108 Oliveira: Elementos, tomo VI, pp. 221-222.

109 Oliveira, Elementos, tomo VI, pp. 223-227.

110 SEPÚLVEDA, Christovam Ayres de Magalhães: Historia organica e politica do exercito portuguez, Provas, Lisboa, Imprensa Nacional, 1902, vol. I, p. 45.

111 Oliveira: Elementos, tomo VI, p. 239.
} 
Que se sabia que pouco havia de dar. A preferência por tirar dinheiro com «menos detrimento» acaba por cair sobre o pão, o que sempre se evitara. Será imposto sobre as moendas, e de um vintém por cada alqueire de trigo que se moer, e cinco réis por cada alqueire de centeio, milho e cevada. Será tributo à produção a cobrar durante dois anos. Para amenizar as coisas, a realeza vai acenando com o levantamento de alguns outros tributos, que não indica ${ }^{112}$. Mas que vai acontecer, deixando de cobrar-se de imediato a nova contribuição dos 8 réis nas canadas de vinho, a meia décima, maneios dos oficiais que tivessem tenda aberta e os que vivem de seu trabalho braçal, o sexto quartel da décima e o outros tributos recentes. No final do ano deixar-se-iam de pagar os tributos «novíssimos» sobre o couro, arroz, carne seca e o quinto quartel da décima. Assim, a décima tornaria a ser de $10 \%$ em $1662^{113}$.

No entanto, a impopularidade do novo tributo sobre as moendas era tal que os Vinte e Quatro de Lisboa viram sair-lhes «ao encontro diversas pessoas ecclesiasticas e seculares, dizendo em altas vozes os haviam de matar e queimar, por serem contra o povo e nada obrarem a seu favor». As regateiras da Ribeira também se amotinam. $O$ juiz do Povo é insultado e chamam-lhe o «juiz da fome»114. A previsão de dificuldades na cobrança leva a Rainha a sobrestar.na sua aplicação, aguardando sugestões para se arranjar o dinheiro necessário. Mas a regente precavera-se: ouvira os conselhos de Estado e da Guerra, a Junta dos Três Estados, o Desembargo do Paço e uma junta de ministros de todos os tribunais. E não tinham conseguido encontrar melhor saída ${ }^{115}$. Com o acréscimo das dificuldades financeiras e com o aumento da resistência popular ao novo tributo "geralmente odioso» a atitude da regente - e dos ministros que com a soberana tratavam na matéria - torna-se menos impositiva. Há uma cedência às reivindicações do povo miúdo.

Mas este sente a força do seu lado, talvez porque não estivesse muito convencido da boa aplicação das somas que anteriormente aceitara pagar. Por isso quer que se compute "o valor dos impostos e mais bens destinados até ás ultimas côrtes do anno de 1654 , e os que do tempo d'ellas cresceram em diante, e ser presente a despeza». Assim ficava mais fácil deliberar. Os Vinte e Quatro sentiam-se representantes dos «pobres officiaes mechanicos, lavradores e mais vassalos de semelhante condição» ${ }^{116}$. Aproveitavam a fraqueza da fazenda real para aumentar a relevância de serem ouvidos. Pelo menos isso. E de emperrarem os lançamento de novos tributos. Porque eram inelutáveis. Agora propunham que se dobrasse a décima, aumentando-a para $20 \%$, o que passaria a ser o quinto. Mas o senado da câmara não concorda. Porque «a decima direita não suppria a todas as despezas da guerra por não a pagarem todos com a pontua-

112 Oliveira: Elementos, tomo VI, p. 240.

113 Oliveira, Elementos, tomo VI, pp. 241-243.

114 Oliveira: Elementos, tomo VI, p. 250.

115 OLIVEIRA: Elementos, tomo VI, p. 252.

116 Oliveira: Elementos, tomo VI, p. 254. 
lidade precisa, e estarem grandes sommas por cobrar». Chegaria se todos a pagassem como deviam. A dificuldade continuava a estar na falta de deliberação das cortes, que continuavam por reunir. A Câmara prefere outros expedientes, como dobrar as sisas. Havia que aliviar o tributo das décimas ${ }^{117}$. Tudo para se escusarem as imposições sobre as moendas.

Tratava-se então - para além da temida intensificação da guerra - de uma negociação com a Inglaterra de que se esperava reputação e segurança para o reino. Era, com efeito, um momento de especial melindre, o da negociação final e concretização do casamento da infanta D. Catarina com o rei Carlos II de Inglaterra, em 1661. Tanto se justificava essa aliança que o governo está disposto a valer-se «de tudo o que se possa tirar» dinheiro. A câmara deve logo vender 600 mil réis de foros para arranjar 50 mil cruzados ${ }^{118}$. Além do mais -e o mais era muito - a coroa portuguesa deveria pagar dois milhões de cruzados de dote. De que metade deveria ser satisfeita com o embarque da nova rainha. Para que não havia liquidez, tendo a quantia que ser paga em pedraria, jóias, açúcar e outras mercadorias, que seriam vendidas em Londres. O dinheiro assim apurado seria entregue ao rei da Grã-Bretanha, em moeda inglesa, no prazo de dois meses ${ }^{119}$. Mais um esforço que os povos teriam que suportar, porque a aliança com a Inglaterra se antevia vital para o arranque final da guerra e a consecussão da paz. Como foi: Porque Carlos II serviu de mediador no acordo com os Países Baixos - o que ocorreu a 6 de Agosto de 1661 - e depois com Castela ${ }^{120}$. Mas dinheiro não havia e a câmara de Lisboa viu-se obrigada a pôr à venda juros de vinte o milhar para se prefazer a quantia de 50 mil cruzados que eram precisos de imediato ${ }^{121}$. Mais uma vez. Todavia, já não havia quem os tomasse. As rendas camarárias estavam exaustas e foi preciso que o governo consignasse esses juros nas naus da Índia, ferrarias, linhos e outras. Ingressos ainda tidos por seguros. Ao mesmo tempo a câmara procura arranjar dinheiro com venda de foros ${ }^{122}$. Uma nova actuação parece desenhar-se com a reforma do regimento dos novos direitos da chancelaria. Embora se cobrassem desde a reunião das cortes de 1642 , agora se afinam para melhor administração ${ }^{123}$.

Era urgente convocar cortes. Mas vão sendo adiadas, que por isto ou por aquilo não convinha, nem havia sossego quando o inimigo se aproximava das fronteiras ou se mostrava mais aguerrido. Como começa a ser neste fim dos

\footnotetext{
117 Oliveira: Elementos, tomo VI, pp. 257-258.

118 Oliveira: Elementos, tomo VI, pp. 256 e 264.

119 SousA, D. António Caetano de: Provas da Historia Genealogica da Casa Real Portuguesa, $2^{\mathrm{a}}$ ed., Coimbra, Atlântida, 1954, vol. VII, pp. 504-505; CASIMIRO, Augusto: Dona Catarina de Bragança, Rainba de Inglaterra, Filha de Portugal, Lisboa, Fundação da Casa de Bragança - Portugália Editora, 1956, 109-142.

120 Oliveira: Elementos, tomo VI, p. 237.

121 OliverRa: Elementos, tomo VI, p. 297.

122 Oliveira: Elementos, tomo VI, pp. 314-315 e 317.

123 Oliveira: Elementos, tomo VI, p. 307.
} 
anos cinquenta - princípio dos anos sessenta . Feita a paz com a França, Portugal é agora a frente de batalha única, para que Castela se vira. A chefia do exército para ataque a Portugal é entregue a D. Juan José de Austria, filho bastardo do rei. Era cada vez mais preciso dinheiro. Algumas dessas receitas eram distraídas das finalidades militares para outras, nomeadamente religiosas $^{124}$. O que a sociedade não contestava.

A tomada do trono por D. Afonso VI em 22 de Junho de 1662 - porque de um golpe de Estado se tratou - vai mostrar uma relação política muito menos autoritária da parte do governo com a câmara de Lisboa. Não menos firme, porém sem imposições que os povos não entendiam - ou que podiam arguir como tal. O Conde de Castelo Melhor (escrivão da puridade) e o Doutor António de Sousa de Macedo (secretário de Estado) lidam com a câmara com mais habilidade do que o grupo que anteriormente rodeava a regente. Pelo menos é o que parece. Não que a fiscalidade tenha abrandado. Muito pelo contrário. $\mathrm{O}$ real d'água deve ser recolhido com a brevidade possível ${ }^{125}$.

Logo para começar o novo governo determina um lançamento por todo o reino «em que todas as pessoas, de qualquer qualidade e condição que sejam, sendo varões, assim paes de familias, como filhos familias, tendo idade em que se confessem, contribuam por cabeça com a quantia que fôr conforme a possibilidade de cada um, não excedendo de oito mil réis a pessoa mais rica». Os miseráveis seriam escusos. Mais uma vez, a cobrança era entregue aos municípios, que nomeariam os responsáveis. Apesar de ser mais um tributo, vinha adoçado com o ser lançado de uma vez e não ficar a constituir um imposto. Era dado como meio «mais igual» que outros por ser de uma só vez e conforme à possibilidade de cada um ${ }^{126}$. E fora sugerido pelos Vinte e Quatro de Lisboa, o que retirava argumentos a qualquer resistência popular ${ }^{127}$. Pouco depois a moeda foi desvalorizada ${ }^{128}$.

Os livros do real d'água começavam a ser vistos, para se averiguar como as cobranças tinham sido feitas. O que vai contra os privilégios dos vereadores da câmara. Mas o secretário de Estado mantém-se firme na sua decisão. E a câmara cede, que sempre se mostrava obediente em seguida ao protesto ${ }^{129}$. É que a câmara de Lisboa estava devendo consideráveis quantias do donativo que entregava em vez da décima - décima das rendas que recebia, que pagava como o pagavam as pessoas que tinham rendas - e suspeitas recairiam sobre as suas cobranças ${ }^{130}$. O Doutor António de Sousa de Macedo tinha experiência destas fiscalizações. Já em 1646 tinha sido encarregado de tomar conhecimento «de

\footnotetext{
124 Oliveira: Elementos, tomo VI, p. 332.

125 SILVA: Collecção, 1657-1674, pp. 78.

126 Oliveira: Elementos, tomo VI, pp. 350-351 e 352-355. .

${ }_{127}$ OliveIRA: Elementos, tomo VI, p. 356.

128 OliveIRA: Elementos, tomo VI, p. 355.

129 Oliveira: Elementos, tomo VI, pp. 367-369 e 370-375.

130 Oliveira: Elementos, tomo VI, pp. 376 e 380-381.
} 
todas e quaesquer fazendas que estiverem confiscadas", trocando-as por ju$\operatorname{ros}^{131}$. Fora uma conversão destinada a aumentar os réditos da realeza.

Mas as coisas tornam a azedar. A câmara não admite intromissões da Junta dos Três Estados. E o senado tem de recordar que «este corpo do tribunal da camara é a mesma cidade de Lisboa, tão nobre, tão antiga, tão leal que ella só serve a V. Mag. ${ }^{\text {de }}$ mais que todo o resto do reino» ${ }^{132}$. O ano de 1663 foi tão apertado que «as necessidades não permittem dilações na cobrança dos effeitos para a guerra». As fiscalizações dos livros das execuções do real d'água continuam, que a secretaria de Estado procurava recuperar o dinheiro que não tinha sido cobrado ${ }^{133}$. Porque foi o ano de mais risco para a restauração e as despesas cresciam. 600 mil cruzados era quanto se gastava nos três meses de campanha no Alentejo $0^{134}$.

À fiscalidade autoritária e um pouco ao acaso dos tempos de D. Luísa de Gusmão estava a substituir-se um Estado que se pretendia bem organizado, que ia buscar o que lhe faltava naquilo que devia ser pago e impunha o escrupuloso cumprimento dos regimentos. $O$ do mesmo modo devia a câmara de Lisboa proceder. Caso contrário, os ministros do senado veriam os seus ordenados servirem para os pagamentos ${ }^{135}$. As relações tornam-se tensas, mas a nova forma de governo começa a mostrar-se mais eficaz. A própria câmara receberá trinta mil cruzados da Junta dos Três Estados para a sustentação da cavala$\mathrm{ria}^{136}$. Nas ordens provenientes da secretaria de Estado sente-se uma muito maior precisão quanto às instruções de contabilidade e arrumação das despesas e pagamento das dívidas. A administração tomara diferente feição.

Agora todos os esforços se concentram na organização militar. Havia que conseguir a paz, e as coisas começam a apresentar-se de feição. Aplicam-se as receitas das imposições às despesas a que se encontravam consignadas, despesas militares de que as câmaras tinham de cuidar. Mas, mesmo assim, há tumultos populares ${ }^{137}$. Havia que pagar o dote da infanta D. Catarina e para isso se dobram as sisas por mais dois anos ${ }^{138}$. Aperfeiçoa-se a cobrança do quinto das comendas e das décimas delas ${ }^{139}$. A exaustão financeira era visível, e a única possibilidade de haver soluções que a todos pudessem convir passava pela convocação de cortes, o que vai sendo adiado ${ }^{140}$. Só em finais de 1667 o rei (agora o regente e governador do Reino D. Pedro) se decide convocá-las.

A guerra aproximava-se do seu termo. A 27 de Janeiro de 1668 reuniam-se as cortes em Lisboa. Jurou-se o príncipe D. Pedro como herdeiro do trono. Mas

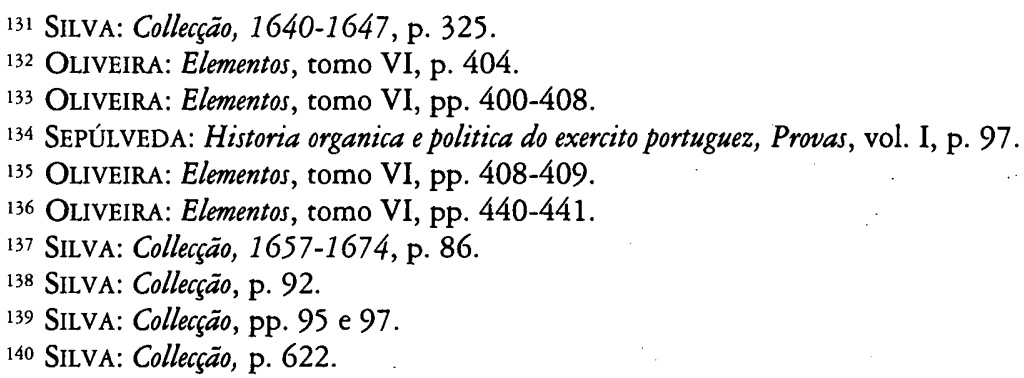


estava a terminar-se a redacção do tratado de paz com Castela. Que foi apresentado aos três estados do reino. A 13 de Fevereiro era coisa feita: aprovava-se a paz «perpétua, firme e inviolável» entre os dois reinos hispânicos ${ }^{141}$. Para durar. Alguns anos. Havia agora que proceder ao pagamento de dívidas, ao dispensar de tropas e atender aos soldados ${ }^{142}$, ao manter dos presídios fronteiriços. A restituição dos bens confiscados aos ausentes em Castela iria provocar longos pleitos $^{143}$. E não se podia descurar a administração do reino, agora sem as angústias de se procurar de tudo fazer dinheiro para sustentar exércitos e armadas. $\mathrm{O}$ tremendo esforço chegava ao seu fim. Ainda iam ser necessárias algumas somas importantes. Mas o pior passara. Todos os tributos de guerra foram levantados a 10 de Abril de 1668, para ter efeito no final do ano ${ }^{144}$. Era o termo de um longuíssimo pesadelo. O reino recobrara a total independência política, mas a crise económica e financeira instalava-se ${ }^{145}$. Para durar alguns anos. A restauração custara muito cara. E com ela modificações estruturais no império. Que implicavam novas políticas. Os piores momentos estavam passados.

\footnotetext{
${ }^{141}$ ErJCeIRA, Conde da: História, vol. IV, p. 536; SOUSA, D. António Caetano de: Provas da História Genealógica da Casa Real Portuguesa, tomo V, Ia . Parte, pp. 78-90.

142 SILVA: Colleç̧ão Chronologica, 1657-1674, p. 143.

143 SILVA: Collecção, p. 147.

144 Oliveira: Elementos, tomo VI, p. 271 e tomo VII, p. 43; SILVA: Colleç̧āo Chronologica, 1657-1674, p. 146

145 GODINHO, Vitorino Magalhães: «Portugal, as frotas do açúcar e as frotas do ouro» in Ensaios, II, Sobre História de Portugal, Lisboa, Sá da Costa, 1978, pp. 425-439.

Hispania, LXIV/1, núm. 216 (2004) 157-182
} 